\title{
Identification of barley cultivars using SDS-PAGE electrophoresis
}

\author{
Janne Roininen, Eero Nissilä, Matti Puolimatka ja Seppo Pulli \\ Roininen, J., NissilÄ, E., Puolimatka, M. \& Pulli, S. 1992. Identification of barley \\ cultivars using SDS-PAGE electrophoresis. Agric. Sci. Finl. 1: 73-82. (Agric. Res. \\ Centre of Finland, Inst. Pl. Breed., SF-31600 Jokioinen, Finland).
}

Sodium dodecyl sulphate-polyacrylamide gel electrophoresis (SDS-PAGE) was applied to cultivar identification. Three different extractions methods were used to extract and fractionate the seed storage protein subunits from crushed single seeds of barley (Hordeum vulgare L.). Fifty-four genotypes including breeding lines and released cultivars were analysed and grouped according to the variation found in their protein banding patterns. In the first extraction, eight genotypes showed unique hordein subunit composition whilst remainder fell into 11 groups of 2 to 8 . The other two extractions were carried out to characterize those genotypes producing identical banding patterns when using the first method. Relative mobility (REM) values for hordein bands were determined.

Genetic background was found to strongly effect the determination of hordein composition of barley genotypes. Those genotypes with largely common ancestry showed often similar hordein composition and were difficult to identify whereas genotypes possessing unique hordein banding patterns had clearly exceptional pedigree. The effect of the row-type on hordein banding pattern was not clear as both two-row and many-row barleys were found to produce identical patterns. Intra-cultivar hordein polymorfism was found in three cultivars.

Key words: cultivar identification, barley, hordein, electrophoresis

Abbreviations used in this article: SDS-PAGE - sodium dodecyl sulphate polyacrylamide gel electrophoresis, 2-ME - 2-mercaptoethanol, DMF - dimethylformamide, BIS - NN'-methylenebisacrylamide, TEMED - NNN'N'-tetramethylethylenediamine, TCA - trichloroacetic acid.

\section{Introduction}

The correct identification of barley cultivars is important to plant breeders for protection of their proprietary rights on cultivars and to crop users for the determination of grain suitability for different end-uses, especially malting. Several approaches have been introduced to enable characterization of genotypes from single or half seeds as a complement to the identification method of visual examination of heritable morphological differencies of whole plants or grains. These techniques, including electrophoresis, isoelectric focusing and chromatography, have been used to obtain qualitative information about the variation in hordein, the alcohol-soluble seed storage protein, dependent upon the genotype and independent on the growth environment. Hordein can be separated into its component polypeptides on the basis of differencies in molecular weight 
(MIFLIN and SHEWRY 1977), isoelectric points (FAVRET et al. 1970, SHEwry et al. 1978 a) and hydrophobicities in chromatographical analysis (Marchylo and Kruger 1984, 1985).

Hordein has been classified into four groups A, B, $\mathrm{C}$, D on the basis of differencies in molecular weights and amino acid compositions (SHEWRY and MifLIN 1985). The A hordeins, less than 20000 in molecular weight, are not regarded as true storage proteins (MIFLIN and SHEWRY 1977, ShEWRY et al. 1978 a, KöIE and Doll 1979) and do not vary sufficiently for cultivar identification (SHEWRY et al. $1978 \mathrm{a}$, SAlCEDO et al. 1980, 1982, ARAGONCILlo et al. 1981). In contrast the $\mathrm{B}$ and $\mathrm{C}$ groups, the major hordeins rangeing in molecular weights from 32000 to 45000 and from 45000 to 80000 respectively, show a wide variation in protein composition and are encoded by two separate but linked multigenic loci Hor2 and Horl located on the short arm of chromosome 5 (JENSEN et al. 1980, SHEWRY and Miflin 1982, Heisel et al. 1986, EnTwistLe 1988). D hordeins, minor components with higher molecular weight, are encoded by locus Hor 3 locating on the long arm of the same chromosome and exhibiting a limited but recognisable polymorphism (SHEWRY et al. 1982, 1983).

In this paper hordein compositions of 54 different barley genotypes were studied using sodium dodecyl sulphate-polyacrylamide gel electrophoresis (SDS-PAGE). The usefulness of this technique for identification of Finnish barley cultivars is discussed.

\section{Material and methods}

\section{Experimental material}

Barley material consisted of all commercial cultivars currently grown in Finland, a specific collection of breeding lines from the Plant Breeding Institute of Agricultural Research Centre, in Jokioinen, Finland, and some foreign cultivars. Twenty-seven two- and many-row genotypes were included in experimental material. Grain samples were obtained from original certified seed material supplied by breeders. Barley cultivar Atem was used for the calibration of gels. Atem seed sample was kindly supplied by B.V. Landbouwbureau Wiersum, Groningen, Netherlands.

\section{Experimental methods}

\section{Hordein extraction}

Three different methods were used to isolate hordein subunits from crushed single seeds (averaged $50 \mathrm{mg}$ in weight) of barley.

In method 1 (modified SMiтH et al. 1986) the samples from all genotypes were mixed with extraction buffer containing $750 \mu \mathrm{l}$ of solution 1 (see table 1) and $250 \mu \mathrm{l}$ of 2 -ME added straight into a 1.5 $\mathrm{ml}$ microfuge tube, extracted for 2 hours at room temperature, mixed several times using a vortex mixer, heated in a boiling water bath for $10 \mathrm{~min}$ and then allowed to cool. The extracts were centrifuged

Table 1. Compositions of three different extraction solutions.

\begin{tabular}{|c|}
\hline Solution 1. \\
$62.5 \mathrm{mM}$ Tris-HCl pH 6,8 \\
$2.0 \%(\mathrm{w} / \mathrm{v}) \mathrm{SDS}$ \\
$0.01 \%(\mathrm{w} / \mathrm{v})$ Pyronin $\mathrm{G}$ \\
$10.0 \%(\mathrm{v} / \mathrm{v})$ Glycerol \\
$7.91 \%(\mathrm{v} / \mathrm{v}) 2-\mathrm{ME}^{\mathrm{a})}$ \\
$15.0 \%(\mathrm{v} / \mathrm{v}) \mathrm{DMF}$ ) \\
\hline Solution 2. \\
$55 \%(\mathrm{v} / \mathrm{v}) 2-\mathrm{propanol}$ \\
$2 \%(\mathrm{v} / \mathrm{v}) 2-\mathrm{ME}$ \\
\hline Solution 3. \\
$65.8 \mathrm{mM}$ TrisHCl $\mathrm{pH} 7,0$ \\
$2.1 \%(\mathrm{w} / \mathrm{v}) \mathrm{SDS}$ \\
$9.2 \%(\mathrm{v} / \mathrm{v})$ glycerol \\
\hline $0.001 \%(\mathrm{w} / \mathrm{v})$ bromophenol blue \\
\hline
\end{tabular}

a) $2-\mathrm{ME}$ and DMF were added prior to use.

at $14000 \mathrm{rpm}$ for $5 \mathrm{~min}$. The supernatants were used immediately for electrophoresis.

Method 2 (modified from SHEWRY et al. 1978 a, b, MARChYlo and LABERGE 1980) was chosen to reveal differencies between genotypes resembling 
each others in their hordein composition in the first extraction. Hordeins were extracted overnight with $750 \mu \mathrm{l}$ of $55 \%(\mathrm{v} / \mathrm{v})$ 2-propanol containing $2 \%$ (v/v) 2-ME at $60^{\circ} \mathrm{C}$. The following morning extracts were centrifuged at $14000 \mathrm{rpm}$ for $5 \mathrm{~min}$ and $100 \mu \mathrm{l}$ of supernatant was taken to be immediately evaporated in a vacuum dryer at $42{ }^{\circ} \mathrm{C}$. After evaporation hordeins were resuspended in $100 \mu \mathrm{l}$ of solution 1 used in the first extraction method. Samples were prepared immediately before electrophoresis.

Method 3 was performed as described by AHOKAS (1988) and was chosen to reveal differencies between genotypes which still gave similar banding patterns in the second method. Hordeins were extracted by heating samples in $712.5 \mu \mathrm{l}$ of solution 3 (see Table 1) for $2 \mathrm{~min}$ in boiling water. The tubes were left overnight at room temperature and $37 \mu \mathrm{l}$ of 2-ME was added on the following morning. Samples were centrifuged at $12000 \mathrm{rpm}$ for $10 \mathrm{~min}$ and analysed electrophoretically during the same day.

\section{Electrophoresis}

SDS-PAGE was carried out using a modification of the discontinuous gel method of LAEMMLI (1970). The stacking gels contained $3.4 \%(\mathrm{w} / \mathrm{v})$ acrylamide, $0.038 \%$ (w/v) BIS, $0.11 \%$ (w/v) SDS, $0.12 \mathrm{M}$ Tris$\mathrm{HCl}, \mathrm{pH} 6.8,0.043 \%$ (w/v) ammonium persulphate and $0.086 \%(\mathrm{v} / \mathrm{v})$ TEMED. The separating gels contained $13 \%(w / v)$ acrylamide, $0.081 \%(w / v)$ BIS, $0.10 \%(\mathrm{w} / \mathrm{v})$ SDS, $0.38 \mathrm{M}$ Tris- $\mathrm{HCl}, \mathrm{pH} 8.8$, $0.025 \%(\mathrm{w} / \mathrm{v})$ ammonium persulphate and $0.051 \%$ $(\mathrm{v} / \mathrm{v})$ TEMED. The running buffer contained $0.19 \mathrm{M}$ glycine, $0.1 \%(\mathrm{w} / \mathrm{v})$ SDS and $0.025 \mathrm{M}$ Tris, $\mathrm{pH} 8.3$.

Eighteen samples $(25 \mu \mathrm{l})$ - nine genotypes with two replicates - were loaded onto each slab gel and subjected to overnight electrophoresis at $10.5 \mathrm{~mA}$ constant current per $200 \times 160 \times 1.5 \mathrm{~mm}$ slab gel on a Bio-Rad Protean II dual slab electrophoresis cell. The gels were run at $15^{\circ} \mathrm{C}$ until the marker dye had reached the bottom of the separating gel.

Following electrophoresis, gels were fixed in $15 \%$ TCA for $30 \mathrm{~min}$, rinsed in distilled water and stained overnight at room temperature in the staining solution containing $5.5 \%(\mathrm{w} / \mathrm{v}) \mathrm{TCA}, 6.5 \%$ glacial acetic acid, $18 \%(\mathrm{v} / \mathrm{v})$ methanol, $0.006(\mathrm{w} / \mathrm{v})$ Coomassie Blue G250 and $0.019 \%$ (w/v) Coomassie Blue R250. The gels were destained in $10 \%$ TCA for 4 hours, photographed and dried with Bio-Rad Slab Dryer. The variation in hordein bands was quantified by using the relative mobility value (REM-value) recommended by UPOV (International Union of Protection of New Varieties of Plants). REM-values were determined in relation to the migration distance of a specific B-hordein band (given REM-value 100) of the calibration cultivar Atem.

\section{Results}

\section{Hordein extraction}

Clear and reproducible hordein banding patterns in $\mathrm{B}, \mathrm{C}$ and $\mathrm{D}$ hordein groups were obtained with all three extraction methods used in the study. The A hordeins did not give consistent patterns - which was expected as the extraction methods are more suitable for B, C and D hordeins. Therefore A hordeins were not included in the characterization of genotypes. Variation was not found between the replicate samples (7-11 reps in method 1, 4 reps in method 2 and 4 reps in method 3 ) of any genotype except three cultivars Potra, Triumph and Etu, which showed polymorphism in their hordein patterns. Genotypes analysed with all three extraction methods seemed to produce almost identical hordein patterns in each extractions, showing mainly the same major bands with variation in their migration distances. Extraction methods 1,2 and 3 produced respectively 44,43 and 38 protein bands, in which variation was found (Figs. 1, 2 and 3). The efficiency of extraction methods 1 and 2 to separate hordein into its component subunits was found to be nearly the same. Method 1 did not give variation in $\mathrm{C}$ hordeins as effectively as the other two procedures. However, method 1 seemed to be the most suitable for the extraction of D hordeins, as six different Dbands (three of which were used in identification) 
could be observed with this procedure. The extraction method 3 produced the largest hordein fraction separation, but no clear difference compared to other methods was found as many of the bands were not clear enough to be used in identification. Method 1 gave the most distinctive bands, possibly due to the shorter migration distances of the bands than in the other methods.

\section{Cultivar identification}

The variation in characters used in cultivar identification must entirely be based on genetic differencies. In this study only the presence or absence of protein bands was accepted as sufficient evidence to separate genotypes, whereas the variation in the staining intensities of the bands was not regarded as a reliable determinant for cultivar identification.

With the first extraction method hordein fractions were separated from all 54 genotypes. Eight genotypes had unique hordein compositions. Two of these were many-row and six two-row barleys. The remaining 46 genotypes fell into 11 groups (numbered 1 to 11 ) the largest containing eight genotypes (Table 2, Fig. 1). Groups 1, 2, 3, 4 and 6 contained both two-row and many-row barleys. Group 5 consisted of only many-row barleys whereas genotypes in groups $7,8,9,10$ and 11 were all of two-row type. The relation between

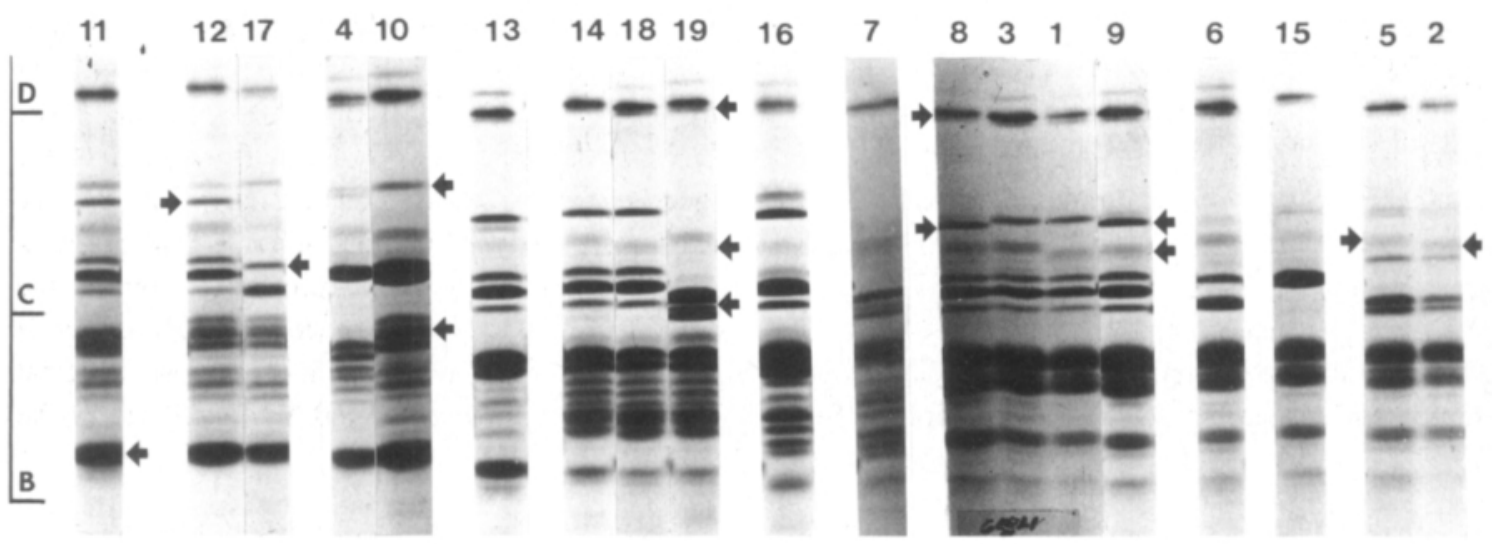

Fig. 1. Hordein banding patterns of 11 cultivar groups and 8 single genotypes obtained by the extraction method 1 . Arrows indicate the special discriminating bands marked with blots in Table 3 .

$\begin{array}{lllllllllllllllllll}7 & 7 & 3 & 3 & 3 & 8 & 9 & 1 & 10 & 4 & 11 & 2 & 2 & 2 & 2 & 5 & 5 & 6 & 6\end{array}$

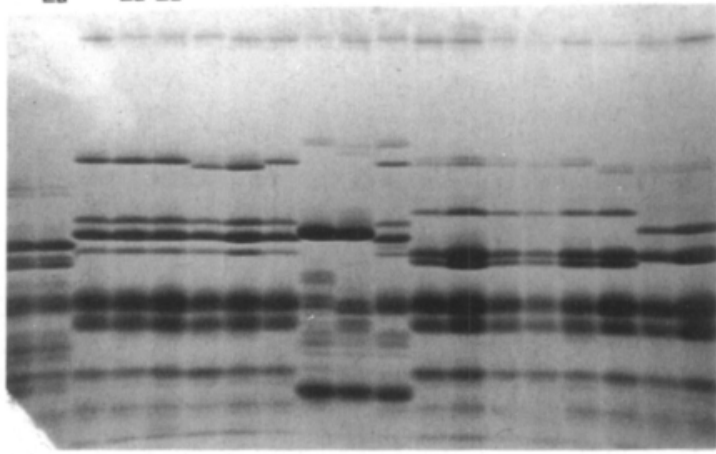

Fig. 2. Hordein patterns of method 2. Groups are indicated as in Table 2.

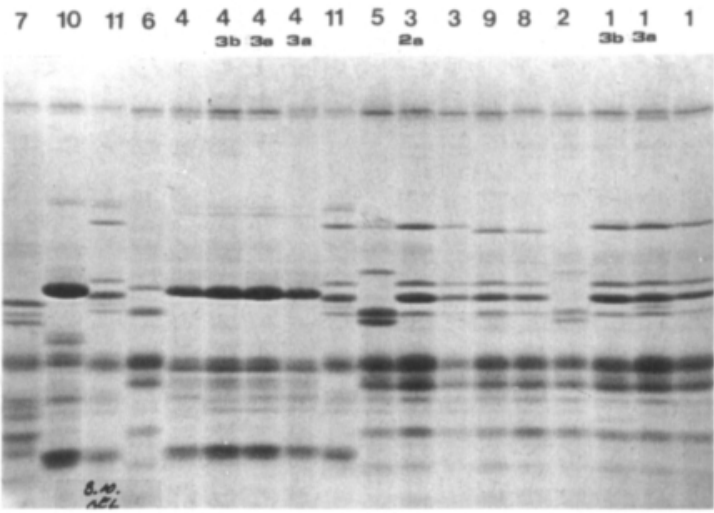

Fig. 3. Hordein petterns of method 3. Groups are indicated as in Table 2. 
hordein patterns of cultivar groups and the REMvalues of 44 varying bands in extraction 1 is presented in Figure 1 and Table 3. Bands used in separating genotypes of closely resembling cultivar groups are indicated with blots in Table 3 and with arrows in Figure 1.

No drastic improvement was obtained in identification with methods 2 and 3 (Figs. 2 and 3). Only a few genotypes could be eliminated from the groups obtained by the first extraction (Table 2). However, the extractions 2 and 3 could separate out four two-row barleys (Jo 1587, Jo 1681, Jo 1490 and Jo 1792) from groups 1 and 3 and one two-row barley (Jo 1677) from group 6. Interesting also, two many-row barleys (Jo 1669 and Jo 1755) could be dissected out from group 4.

Compared to the common identification of cultivars by morphological characters of grain (base of lemma, spiculation of lemma nerves, rachilla hair lenght) in many cases electrophoresis could produce more accurate identification. For example, released cultivars identical in grain morphology [Pomo, Pokko, Kilta], [Kalle, Agneta], [Kustaa, Kymppi] could be identified on the basis of hordein patterns. On the other hand, some cultivar pairs [Arra, Niina], [Pomo, Etu],
[Potra, Pohto], [Ida, Mette] remained undistinguishable.

In many cultivar groups established by the method 1 the influence of common genetic background of genotypes can be noticed. For example, in group 3 (Table 2) all genotypes are derived from an old breeding line Jo 0490 (Fig. 4). Similarily, cultivars Otra, Mari and Varde join the pedigrees of the genotypes in groups 2, 4 and 6, respectively.

\section{Hordein polymorphism within cultivars}

Three cultivars, Potra, Triumph and Etu, showed intra-cultivar variation in their hordein composition. All extractions of Potra were prepared from seeds of the same elite seed material. All seven seeds analysed with method 1 showed identical banding patterns. In contrast, two different banding patterns (named a and b) were observed with both methods 2 and 3 (Fig. 5). Six seeds were analysed with method 2 giving patterns $a$ and $b$ in a ratio of $4: 2$, while with method 3 the two analysed samples gave the relation of $1: 1$. It was noticed that the b-type patterns were identical in the both extractions 2 and 3 (Fig. 5). Thus the

Table 2. The cultivar groups obtained by the first extraction method. Genotypes marked with superscripts 2 and 3 were divided by the second and the third extraction methods, respectively, into subgroups shown by superscript letters. Two-row barleys are indicated with bold font.

\begin{tabular}{|c|c|c|c|c|c|c|c|c|c|c|}
\hline $\begin{array}{c}\text { Group } \\
1\end{array}$ & $\begin{array}{c}\text { Group } \\
2\end{array}$ & $\begin{array}{c}\text { Group } \\
3\end{array}$ & $\begin{array}{c}\text { Group } \\
4\end{array}$ & $\begin{array}{c}\text { Group } \\
5\end{array}$ & $\begin{array}{c}\text { Group } \\
6\end{array}$ & $\begin{array}{c}\text { Group } \\
7\end{array}$ & $\begin{array}{c}\text { Group } \\
8\end{array}$ & $\begin{array}{c}\text { Group } \\
9\end{array}$ & $\begin{array}{c}\text { Group } \\
10\end{array}$ & $\begin{array}{c}\text { Group } \\
11\end{array}$ \\
\hline Pomo & Pohto & Pokko & Kustaa & Kilta & Arra & Prisma & Kymppi & Jo 1610 & Ida & Atem \\
\hline Etu & Potra & Jo 1658 & Jo 1724 & Jo 1546 & Niina & Jo 1607 & Jo 1800 & Jo 1612 & Mette & Jo 1790 \\
\hline Jo 1439 & Loviisa & Jo 1730 & Jo $1605^{3 a}$ & Jo 1599 & Jo 1770 & Jo $1626^{2 a}$ & & & & \\
\hline Jo 1660 & Jo 1676 & Jo 1742 & Jo $1669^{3 \mathrm{~b}}$ & Jo $1632^{2 a}$ & Jo $1677^{2 \mathrm{a}}$ & & & & & \\
\hline Jo 1678 & Jo 1739 & Jo 1782 & Jo $1755^{3 \mathrm{c}}$ & & & & & & & \\
\hline Jo 1734 & Nord $^{2 a}$ & Jo $1490^{2 a}$ & & & & & & & & \\
\hline Jo $1587^{3 a}$ & Eero $^{2 b}$ & Jo $1792^{2 a}$ & & & & & & & & \\
\hline Jo $1681^{3 b}$ & & & & & & & & & & \\
\hline
\end{tabular}

Genotypes having unique hordein pattern in extraction 1 are numbered 12 to 19: Agneta (12), Kalle (13), Triumph (14), Jo 1545 (15), Jo 1575 (16), Jo 1589 (17), Jo 1621 (18) and Jo 1801 (19). 
Table 3. REM-values of cultivar groups obtained by the first extraction method. The groups having hordein patterns resembling each other are presented in the same column.

\begin{tabular}{|c|c|c|c|c|c|c|c|c|c|c|c|c|c|c|c|c|c|c|c|c|c|}
\hline \multirow{2}{*}{$\begin{array}{l}\text { REM- } \\
\text { value }\end{array}$} & \multirow{2}{*}{\begin{tabular}{|c|} 
Atem \\
11 \\
\end{tabular}} & \multicolumn{20}{|c|}{ Group number } \\
\hline & & \multicolumn{2}{|c|}{$12 / 17$} & \multicolumn{2}{|c|}{$4 / 10$} & \multirow[t]{2}{*}{13} & \multicolumn{3}{|c|}{$14 / 18 / 19$} & \multirow{2}{*}{\multicolumn{2}{|c|}{16}} & \multirow[t]{2}{*}{7} & \multicolumn{5}{|c|}{$8 / 3 / 1 / 9$} & \multirow[t]{2}{*}{6} & \multirow{2}{*}{$\frac{15}{*}$} & \multicolumn{2}{|c|}{$5 / 2$} \\
\hline 35.5 & & * & & & & & & & & & & & & & & & & & & & \\
\hline 36.3 & * & & $*$ & & * & & * & & * & & 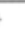 & * & $\bullet$ & & & & & & & & \\
\hline 36.8 & & & & * & & * & & $\bullet$ & & & & & & & * & ** & & * & & * & * \\
\hline 521 & * & * & $*$ & & $\bullet$ & & & & & & 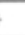 & & & & & & & & & & \\
\hline 55.1 & * & $\bullet$ & & & & * & * & * & & & . & & & & * & * & & & * & & \\
\hline 55.6 & & & & & & & & & & & & & $\bullet$ & 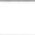 & & & $\bullet$ & & & & \\
\hline 560 & & & & & & & & & & & & & & & & & * & & & & \\
\hline 59.8 & * & * & & * & & * & * & & * & & & & * & $*$ & * & & & * & & $\bullet$ & \\
\hline 60.7 & & & & & * & & & $\bullet$ & & & 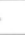 & & & & & & $\bullet$ & & & & \\
\hline 61.5 & & & & & & & & & & & & & & & & $\bullet$ & & & & & $\bullet$ \\
\hline 63.2 & & & & & & & & & & & & & & & & & & & & * & * \\
\hline 65.4 & * & * & & & & * & * & * & & & & & * & * & * & ** & & & & & \\
\hline 66.7 & & & $\bullet$ & & & & & & & & & & & & & & & * & & & \\
\hline 67.1 & & & & * & * & & & & & & & & & & & & & & * & & \\
\hline 67.9 & * & * & & & & * & * & * & & & 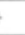 & & * & * & * & ** & & & & & \\
\hline 69.7 & & & & & & & & & $\bullet$ & & & $*$ & & & & & & & & & \\
\hline 70.9 & * & $*$ & $*$ & & & * & * & * & & & 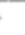 & & * & * & * & * * & * & * & & * & \\
\hline 72.2 & & & & & & & & & $\bullet$ & & & * & & & & & & & & * & * \\
\hline 73.5 & & & & & & & & & $\bullet$ & & & * & & & & & & & & & \\
\hline 75.6 & & * & * & & $\bullet$ & & & & & & & & & & & & & & & & \\
\hline 77.8 & & * & $*$ & & $\bullet$ & & * & * & * & & & & & & & & & & & & \\
\hline 78.6 & * & * & * & & $\bullet$ & & & & & & & $*$ & & & & & & & & & . \\
\hline 79.9 & & & & * & & * & * & * & * & & & & * & * & * & ** & * & * & * & * & * \\
\hline 80.3 & * & * & * & & * & & & & & & & * & & & & & & & & & \\
\hline 81.2 & & & & & & & & & & & & & & & & & & & & & \\
\hline 81.6 & * & & & * & & * & * & * & * & & & & & & & & & & & & \\
\hline 82.9 & & & & & & & & & & & & & * & * & * & * * & * & * & * & * & * \\
\hline 84.2 & & & & * & & & * & * & * & & 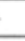 & & & & & & & & & & \\
\hline 85.0 & * & * & $*$ & * & * & & & & . & & & & * & * & * & * * & * & * & * & * & * \\
\hline 86.8 & & & & & & & * & * & * & & & & & & & & & & & & \\
\hline 87.2 & * & * & * & * & * & * & & & & & & * & & & & & & & & & \\
\hline 889 & & & & & & & * & * & * & & & * & & & & & & & & & \\
\hline 89.7 & * & * & * & & * & * & * & * & * & & & & & & & & & & & & \\
\hline 90.2 & & & & & & * & * & * & * & & & $*$ & & & & & & & & & \\
\hline 91.9 & & & & & & & * & * & * & & & & & & & & & & & & \\
\hline 93.2 & & & & & & & & & & & & & * & 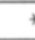 & * & ** & * & * & * & * & * \\
\hline 93.6 & & & & & & & * & * & * & & & * & & & & & & & & & \\
\hline 94.0 & & & & & & & & & & & & * & & & & & & & & & \\
\hline 96.2 & & & & & & & & & & & & * & & & & & & & & & \\
\hline 97.8 & & & & & & & & & & & & * & & & & & & & & & \\
\hline 100.0 & $\bullet$ & * & * & & * & * & & & & & & & & & & & & & & & \\
\hline 100.9 & & & & & & & * & * & $*$ & & & & & & & & & & & & \\
\hline 101.7 & & & & & & & & & & & & & * & * & * & * * & * & * & * & * & \\
\hline 103.0 & & & & & & * & & & & & & * & & & & & & & & & \\
\hline
\end{tabular}




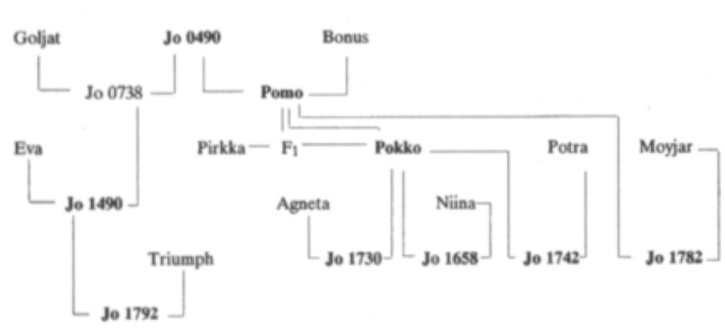

Fig. 4. The genetic background of cultivars in hordein pattern group 3 (tested cultivars are shown with bold font).

biotype ratio of Potra is about 4:1. Cultivar Triumph showed two different banding patterns in extraction 1 in relation of 12:1, whereas in Etu three different patterns were observed in relation of 23:1:1 (different banding patterns of Triumph and Etu are not shown in this paper).

\section{Discussion}

The aim of using biochemical techniques in cultivar identification is to provide accurate information about characters where genetic variability is larger than in morphological traits currently used in the characterization of cultivars. In this study we compared three different extractions for use in identification of barley cultivars by one-dimensional SDS-PAGE. In order to regard electrophoretically obtained hordein pattern variation as a reliable identification method, differencies between genotypes must be reproducible, clear and genetically determined. Therefore the absence or the presence of a protein band can be seen as a sufficient indicator of genetic variation, whereas the intensity of the protein bands can vary according to the protein content being quantitative in nature. However, sometimes the determination of the existence - presence or absence - of a protein band with weak staining intensity is problematic, and a sufficient amount of replications is necessary to confirm this variation as also the heterogeneity within a cultivar. In this experiment many faint and unrepeatable bands were seen in B, C and D hordein groups in addition

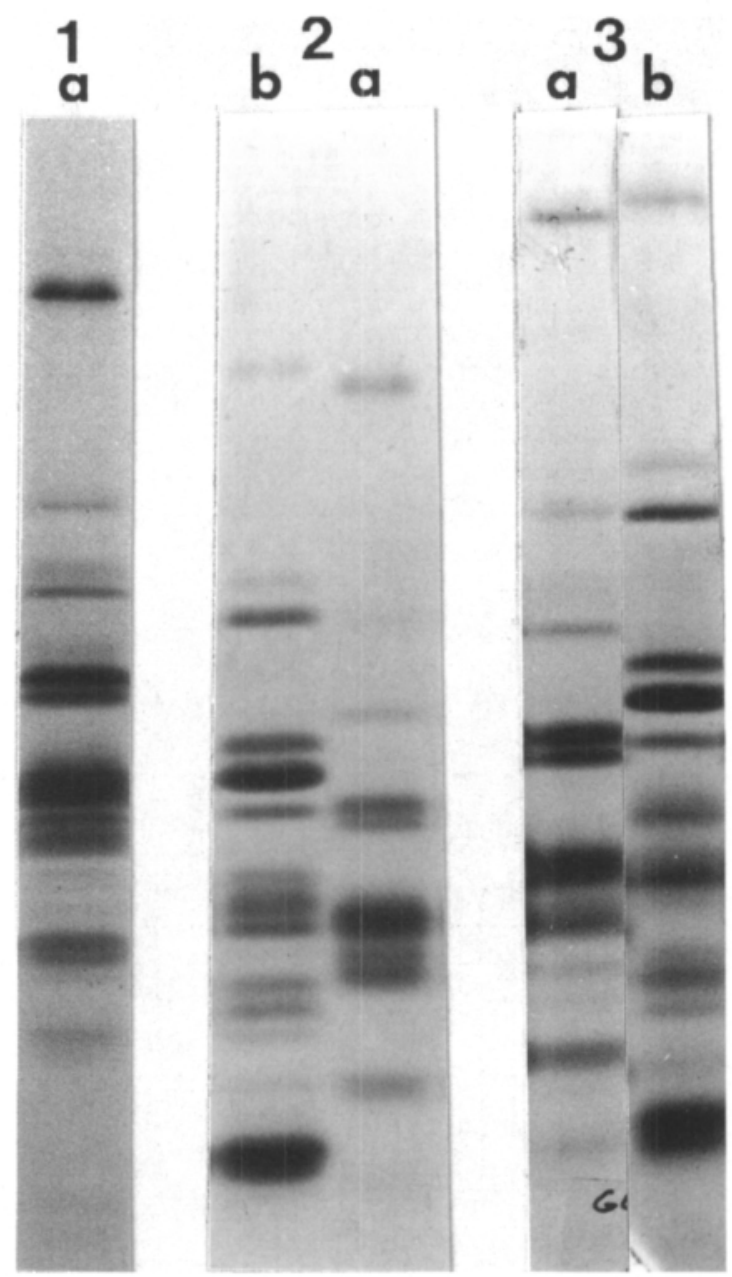

Fig. 5. Biotypes of cv. Potra. Numbers indicate the extractions and letters show the biotypes.

to the clearly observable protein fractions used in identification.

In general, the exact biochemical effects of extractions on hordeins are mainly uncontrolled and the construction of a special extraction solution to express putative hordein fraction variation is impossible. The efficiency of different extractions can thus only be determined by studying their effect on tested cultivars - in other words, the efficiency and suitability of extractions is measurable only in relation to the experimental material. In this study the material mainly consisted of Finnish barley genotypes possessing relatively 
narrow genetic variation in their background. The variation among $\mathrm{D}$ hordeins was found to be larger than reported in earlier studies (SHEWRY et al. 1982) and this variation was also suitable for identification of tested genotypes. The further development of electrophoretical identification of Finnish barley cultivars should exploit not only the variation found in $\mathrm{B}$ and $\mathrm{C}$ hordein but also that in D hordein.

In this study the extraction methods showed little differencies in their ability to separate hordein fractions in terms of the number of different bands. In contrast, there was a clear difference in the sharpness of bands, method 1 giving the best results. This was possibly due to the lower binding of SDS to proteins as a consequence of the high consentration of 2-ME. As a result the migration distances of protein fractions were shorter than in the extractions 2 and 3 in the same running conditions. The best separation of $\mathrm{D}$ hordeins was achieved with method 1, although straight comparison of the extractions is limited as some of the cultivars, for example Agneta and Jo 1545, which showed a specific D hordein compositions, were not analysed with extractions 2 and 3. Method 3 produced the highest frequency of different hordein subunits. This was supposed to be a consequence of the addition of 2-ME (which boils at lower temperature than alcohol) only after the cooling the boiled samples (MÄLKÖNEN 1984).

In this study the distinctiveness of cultivars could be improved by using electrophoretical identification compared to the traditional visual examination of seed morphology. The hordein pattern did not provide the ultimate 'finger print', but electrophoresis can be used as a cheap and quick complement to obtain more correct identification. According to our results there is only limited possibilities to exploit the existing hordein variation by modifying the extraction procedure. The genetic background of experimental material determines the efficiency and suitability of extraction. In our study the cultivars having gene material from different pools performed in many cases unique hordein patterns (for example
Triumph, Agneta, Kalle, Jo 1545 and Jo 1589) or formed groups according to genetic similarity. The influence of common genetic background is due to the inheritance of hordein pattern: studies on biotypes have shown that bands not present in the parents cannot be found in progeny and that parents are also more diverse in their hordein composition than offspring due to the linkage of hordein loci (Borisov et al. 1989, POMORTSEv et al. 1989). Although the function of hordein genes in relation to morphological traits was not examined in this paper the electrophoretical procedure used in this study show evidence about linkage between ear type and hordein composition.

Polymorphism in hordein banding patterns within the same cultivar indicates that the purification on the basis of morphological characters does not always ensure cultivar homogeneity in hordein pattern. In purifying breeding programmes the hordein pattern should be used as one selection criteria to obtain pure lines. The polymorphism of $\mathrm{cv}$. Triumph noticed in this study has also been reported earlier (O'FARRELL 1987); the three biotypes of cv. Etu seem more likely to be seed contamination. It would be interesting to test the similarity of the biotypes of cv. Potra compared to its parental hordein patterns.

As a conclution of this study the results indicate that modification of hordein extractions for SDSPAGE give only limited possibilities to exploit the genetic variation strongly affected by the genetic background of genotypes. The 'multi-step electrophoresis' seems to have potential for more precise cultivar identification. To attain absolute cultivar fingerprinting analysis at the DNA level is needed. 


\section{References}

AноKAS, H. 1988. High-lysine gene segregation distorted in the barley cross Risö 1508 x Crypt CI 1090: Patterns of endosperm proteins by an electrophoretic method. Hereditas 108: 129-131.

Aragoncillo, C., Sanchez-Monge, R. \& Salcedo, G. 1981. Two groups of low molecular weight hydrophobic proteins from barley endosperm. J. Exp. Bot. 32: 1279 . 1286.

Borisov, Y. M., Shevtsova, L. N., Zobova, N. V. \& SurIN, N. A. 1989. Characterization of component composition of hordeins of spring barley varietes in East Siperian region. Sov. Agric. Sci. 12: 1-5.

ENTwISTLE, J. 1988. Primary structure of a C-hordein gene from barley (Hor-1 locus, storage proteins). Carlsberg Res. Commun. Vol. 53: 247-258.

Favret, E. A., Manghers, L., Solari, R., Avila, A. \& MoNESIGLIO, J. C. 1970. Gene control of protein production in cereal seeds. In: Improving Plant Protein by Nuclear Techniques. Int. Atomic Energy Agency, Vienna. p. 8797.

Heisel, S. E., Peterson, D. M. \& Jones, B. L. 1986. Identification of United States barley cultivars by sodium dodecyl sulfate polyacrylamide gel electrophoresis of hordeins. Cereal Chem. 63(6): 500-505.

Jensen, J., Jörgensen, J. H., Giese, H. \& Doll, H. 1980. Linkage of hordein loci Hor-1 and Hor-2 with the powdery mildew resistance loci Mlk and Mla on barley chromosome 5. Theor. Appl. Genet. 58: 27-37.

KöIE, B. \& DolL, H. 1979. In: Seed Protein Improvement in Cereals and Grain Legumes. Vol. 1. International Atomic Energy Agency, Vienna. p. 205.

LAEMMLI, U. K. 1970. Cleavage of structural protein during the assembly of the head of the bacteriophage T4. Nature 227: 680 .

Marchylo, B. A. \& LABerge, D. E. 1980. Barley cultivar identification by electrophoretic analysis of hordein proteins. 1. Extraction and separation of hordein proteins and enviromental effects on the hordein electrophoregram. Can. J. Sci. 60: 1343-1350.

— \& KRUGER, J. E. 1984. Identification of Canadian barley cultivars by reversed-phase high-performance liquid chromatography. Cereal Chem. 61: 295.

— \& KRUGER, J. E. 1985. Assessment of RP-HPLC columns to separate hordein proteins and identify cultivars of barley and barley malt. J. Am. Soc. Brew. Chem. 43: 29.

Miflin, B. J. \& Shewry, P. R. 1977. In: Techniques for the Separation of Barley and Maize Proteins. Publ. by the Commission of the European Communities, Luxembourg. p. 13-21.

MĂLKÔNEN, P. 1984. Orgaaninen kemia. 285 p. 6. painos. Otava, Keuruu, Finland.
O'FARRELL, D. D. 1987. The problems with varietal identification. Aspects of Appl. Biol. 15: 559-567.

Pomortsev, A. A., Bugril, O. V., Netsvetaev, V. P., Vovchuk, S. V., Malinovski, V. A., LeVitskiI, A. P. \& Sozinov, A. A. 1989. Associations of alleles of hordein coding loci with some grain quality parameters in barley. Sov. Genet. Vol. 24(11): 1389-1393.

Salcedo, G., Sanchez-Monge, A., Argamenteria, A. \& ARAGONCILlo, C. 1980. The A-hordeins as a group of salt soluble hydrophobic proteins. Plant Sci. Lett. 19: 109-119.

-, Sanchez-Monge, A. \& Aragoncillo, C. 1982. The isolation and characterization of low molecular weight hydrophobic salt soluble proteins from barley. J. Exp. Bot. 33: 1325-1331.

Shewry, P. R., Pratt, H. M. \& Miflin, B. J. 1978 a. Varietal identification of single seeds of barley by analysis of hordein polypeptides. J. Sci. Fd Agric. 29: 587596.

—, Ellis, J. R. S., Pratt, H. M. \& Miflin, B. J. A. 1978 b. A comparison of methods for the extraction and separation of hordein fractions from 29 barley varieties. J. Sci. Fd. Agric. 29: 433-441.

- , Field, J. M., Parmar, S. \& Miflin, B. J. 1982. 'D' hordein, a new group of prolamin storage proteins in barley. Barley Genet. Newsl. Vol. 12: 28-29.

- \& MifLIN, B. J. 1982. Genes for the storage proteins of barley. Qual. Plant Mater. Veg. 31: 251- 267.

- , Finch, R., Parmar, S., Franklin, J. \& Miflin, B. J. 1983. Chromosomal location of Hor-3, a new locus governing storage proteins in barley. Heredity 50: 179 .

— , Miflin, B. J. 1985. Seed storage proteins of economically important cereals. In: Pomeranz Y. (ed.). Advances in Cereal Science and Technology. Vol. 7. Am. Assoc. Cereal Chem. St. Paul, MN. p. 1-84.

Smith, D. B., Lister, P. R. \& Hanson, P. R. 1986. Discrimination of barley varietes by electrophoresis of endosperm proteins extractable into a mixture of sodium dodecyl sulphate, 2-mercaptoethanol and dimethylformamide. J. Cereal Sci. 4: 107-116.

Manuscript received December 1991

Janne Roininen

Eero Nissilä

Matti Puolimatka

Seppo Pulli

Agricultural Research Centre of Finland

Institute of Plant Breeding

SF-31600 Jokioinen, Finland 


\title{
SELOSTUS
}

\section{Ohran lajiketunnistus SDS-PAGE-elektroforeesilla}

\author{
Janne Roininen, Eero Nissilä, Matti Puolimatka ja Seppo Pulli \\ Maatalouden tutkimuskeskus
}

Tutkimuksessa selvitettiin SDS-PAGE-elektroforeesimenetelmăn soveltuvuutta ohran lajiketunnistukseen. Tutkimuksessa käytettiin kolmea erilaista ohran jyvän varastoproteiinien eli hordeiinien uuttomenetelmäă. Yhteensă 54 erilaista ohran genotyyppiä, joihin kuului kotimaisia ja ulkomaisia lajikkeita sekä kotimaisia jalostuslinjoja, analysoitiin ja ryhmiteltiin niiden elektroforegrammien mukaan. Tutkittujen genotyyppien varastoproteiinivyöhykkeiden suhteelliset liikkuvuudet (REM-arvot) määritettiin suhteessa kontrollina käytettyyn Atem-lajikkeeseen.

Ensimmăisellä uuttomenetelmällă kahdeksan genotyyppiä pystyttiin erottamaan tăysin erilleen muista. Loput koejäsenet jakautuivat 11 ryhmäăn, jotka sisălsivăt kahdesta kahdeksaan koejäsentä. Uutoilla 2 ja 3 pyrittiin erottamaan toisistaan uutossa 1 samaan ryhmään kuuluneet genotyypit, ja näin tarkentamaan lajiketunnistusta.

Verrattuna jyvăn morfologiaan perustuvaan lajiketunnistukseen, käytetyillä elektroforeettisilla menetelmillä pystyttiin useimmissa tapauksissa tarkentamaan identifiointia. Yhteisen geneettisen taustan havaittiin voimakkaasti vaikuttavan eri ohragenotyyppien jyvän varastoproteiinikoostumuksen vaihteluun. Geneettisesti lähellä toisiaan olevien genotyyppien elektroforegrammit havaittiin usein samankaltaisiksi; huomattavan erilaisen geneettisen alkuperăn omaavat genotyypit erottuivat sen sijaan helposti toisistaan. Kaksi- ja monitahoisia ohria ei kaikissa tapauksissa pystytty erottamaan, sillă molemmat tyypit tuottivat eräissä tapauksissa yhtenäisen elektroforegrammin. Varastovalkuaisainekoostumuksen lajikkeen sisäistä vaihtelua havaittiin kolmessa koejäsenessä. 